\title{
Pemenuhan Hak Pendidikan Dasar Di Kota Ambon Saat Pandemi Covid-19
}

\author{
Lucia Charlota Octovina Tahamata ${ }^{1 *}$, Welly Angela Riry ${ }^{2}$ \\ 1, 2, Fakultas Hukum Universitas Pattimura, Ambon, Indonesia \\ *E-mail: luciatahamata69@gmail.com
}

\begin{tabular}{|c|c|}
\hline Dikirim: 09/12/2021 & Dipublikasi: 04/06/2021 \\
\hline Info Artikel & Abstract \\
\hline $\begin{array}{l}\text { Keywords: } \\
\text { Human Right; } \\
\text { Education; Covid-19 }\end{array}$ & $\begin{array}{l}\text { Fulfilling of the Right to Education is a part of Human Rights. The right to } \\
\text { education has become important in line with government policies to work } \\
\text { from home during the Covid } 19 \text { pandemic. During the Covid-19 pandemic } \\
\text { the learning process uses two learning methods, namely the online method } \\
\text { and the offline method. Two learning methods are used for learning but the } \\
\text { process has not been implemented optimally by both teachers and students, } \\
\text { there are always obstacles faced. The purpose of this study was to determine } \\
\text { and study the fulfillment of the right to basic education during the Covid } 19 \\
\text { pandemic. The authors conducted research at the Department of Education } \\
\text { and Culture of Elementary Schools and Junior High Schools in Ambon City } \\
\text { using empirical research methods, data collection techniques through } \\
\text { interviews and observations to students. Based on the results of the research } \\
\text { conducted, the authors found that the distance learning system in schools } \\
\text { in Ambon City was not optimal due to facilities and infrastructure and } \\
\text { mastery of technology. which is still low. Fulfilling the right to education } \\
\text { requires the involvement of all parties, namely the government, educators, } \\
\text { students and parents to work together in the teaching and learning process } \\
\text { during the Covid-19 pandemic. The government, educators, students and } \\
\text { educational administering institutions at a practical level must strive to } \\
\text { develop learning methods with good digital literacy skills so that they need } \\
\text { to be improved through trainings using media for online learning for both } \\
\text { educators, students and parents. }\end{array}$ \\
\hline $\begin{array}{l}\text { Kata Kunci: } \\
\text { Hak Asasi Manusia, } \\
\text { Pendidikan, Covid- } \\
19 .\end{array}$ & $\begin{array}{l}\text { Abstrak } \\
\text { Pendidikan merupakan hak yang melekat pada diri manusia (HAM). Hak } \\
\text { atas pendidikan menjadi penting seiring kebijakan pemerintah untuk } \\
\text { bekerja dari rumah selama pandemi Covid 19. Pada saat terjadi pandemi } \\
\text { Covid-19 proses pembelajaran menggunakan dua metode pembelajaran } \\
\text { yaitu metode online dan metode offline. Dua metode pembelajaran } \\
\text { digunakan untuk pembelajaran tetapi prosesnya belum dilaksanakan secara } \\
\text { maksimal baik oleh guru maupun siswa, selalu ada kendala yang dihadapi. } \\
\text { Tujuan dari penelitian ini adalah untuk mengetahui dan mengkaji } \\
\text { pemenuhan hak atas pendidikan dasar pada saat pandemi Covid 19. Penulis } \\
\text { melakukan penelitian di Dinas Pendidikan dan Kebudayaan Sekolah Dasar } \\
\text { dan Sekolah Menengah Pertama di Kota Ambon dengan menggunakan } \\
\text { metode penelitian empiris, teknik pengumpulan data melalui wawancara } \\
\text { dan observasi kepada siswa. Berdasarkan hasil penelitian yang dilakukan, }\end{array}$ \\
\hline
\end{tabular}


DOI:

10.47268/sasi.v27i2.444

penulis memperoleh hasil bahwa sistem pembelajaran jarak jauh pada sekolah-sekolah di Kota Ambon belum maksimal dikarenakan sarana dan prasarana dan penguasaan teknologi yang masih rendah. Pemenuhan hak atas pendidikan memerlukan keterlibatan semua pihak yaitu pemerintah, para pendidik, para murid dan juga orangtua untuk saling bersinergi dalam proses belajar mengajar semasa pandemi Covid-19. Pemerintah, pendidik, peserta didik dan institusi penyelengara pendidikan pada tataran praktis harus berupaya mengembangkan metode pembelajaran yang dengan kemampuan digital literacy yang baik sehingga perlu ditingkatkan melalui pelatihan-pelatihan menggunakan media untuk pembelajaran daring baik kepada tenaga pendidik, siswa, maupun orang tua murid.

\section{A. PENDAHULUAN}

Mencerdaskan kehidupan bangsa diatur dalam Pembukaan Undang-Undang Dasar Negara Republik Indonesia Tahun 1945 (selanjutnya disingkat UUD NRI Tahun 1945) yang dijabarkan ke dalam Pasal 28 C ayat (1) UUD NRI Tahun 1945, bahwa setiap orang berhak mengembangkan diri melalui pemenuhan kebutuhan dasarnya, berhak mendapat pendidikan dan memperoleh manfaat dari ilmu pengetahuan dan teknomogi, seni dan budaya, demi meningkatkan kualitas hidupnya dan demi kesejahteraan umat manusia dan pasal 32 UUD NRI Tahun 1945 menyatakan bahwa pendidikan merupakan hak dari tiap-tiap warga negara. Hal ini berimplikasi pada pemerintah, berkewajiban mengusahakan dan menyelengarakan satu sistem pendidikan nasional yang diaatur melalui Undang-Undang di satu pihak,setiap warga negara wajib mengikuti pendidikan dipihak lainnya. Sehingga muncul asas keseimbangan antara hak dan kewajiban dalam bidang pendidikan antara pemerintah dengan warga negara secara eksplisit diatur melalui Pasal 31 UUD NRI Tahun 1945.

Pendidikan adalah aset bangsa. Pendidikan mencirikan pembangunan karakter bangsa. Pendidikan yang berkualitas akan serta merta melahirkan kemajuan dan peradaban bangsa.Sebaliknya pendidikan yang buruk akan berimplikasi negatif bagi jalannya roda pemerintahan dan ketersedian partisipasi publik yang cerdas. Begitu pentingnya keberadaan pendidikan, maka terpenuhilah hak atas pendidikan merupakan hak asasi manusia (HAM) ${ }^{1}$

Indonesia dalam menjabarkan hak ats pendidikan tertuang dalam UU No 20 tahun 2003 tentang Sistem Pendidikan Nasional. Hal ini pun bersesuaian dengan Pasal 12 angka 2 Konvesi Ekonomi Sosial dan budaya, bahwa negara perlu menetapkan suatu sistem pendidikan nasional demi menjamin pemuatan hak atas pendidikan dal Undang-Undang menjadi langkah strategis bagi perlindungan $\mathrm{HAM}^{2}$

Awal bulan Maret tahun ini, tepatnya 16 Maret 2020 Presiden Republik Indonsia ,Joko Widodo menginstruksikan word from home, maupun study from home. Work from home/study from home ini tidak terbatas pada dunia usaha melainkan dunia pendidikan sehingga berdampak pada pola pendidikan yang selama ini dilaksanakan. Kebijkaan atas work from home dipertegaskan dengan stategi Pembatasan Sosial Berskala Besar (PSBB) untuk menekan penyebaran virus covid -19.Pemerintah mengeluarkan dua produk hukum terkait Covid -19. Keputusan Presiden Nomor 11 Tahun 2020 tentang Peentapan Kedaruratan Kesehatan

${ }^{1}$ Education is both a human in itself and an indispensable means other human rights. As an empowerment rights, education is the primary vehicle by which economically and socially marginalized adults and children can lift themselves out of poverty and obtain the means to participate fully in their communities "Lihat General comenment nomor 13: The right to education (art 13)

2 Triwahyuningsih, S. (2018). Perlindungan Dan Penegakan Hak Asasi Manusia (Ham) Di Indonesia. Legal Standing: Jurnal Ilmu Hukum, 2(2), 113-121. DOI:http://dx.doi.org/10.24269/ls.v2i2.1242, h. 113

$$
\text { 197|SASI Vol. } 27 \text { No.2, April - Juni } 2021
$$


Masyarakat Covid -19 (Kepres No 11 tahun 2020) disusul peraturan Pemerintah 21 Tahun 2020 tentang Pembatasan Sosial Berskala Besar dalam rangka percepatan penanganan covid -19 .

Dari kedua ketentuan hukum tersebut menjadi tanda bahwa pemerintah memilih stategi PSBB dari opsi karantina kesehatan lain yang ditawarkan UU No 6 Tahun 2018 tentang Karantina Kesehatan. PSBB merupakan respon dari kondisi kedaruratan kesehatan masyarakat yang termuat dalam pasal 59 ayat (1). Ciri khas PSBB terletak dalam strategi peliburan sekolah dan tempat kerja, pembatasan kegiatan keagamaan dan/ atau pembatasan kegiatan ditempat atau fasilitas umum atau dikenal dengan bekerja dirumah, belajar dirumah, beribadah dirumah dan /atau pembatasan berkumpul. PSBB juga memberikan dampak bagi kehidupan masyarakat, terutama dibidang pendidikan. Strategi pendidikanpun berubah secara dratis dari upaya sadar dan terencana (Pasal 31 ayat (2) Undang-Undang Nomor 20 tahun 2003 tentang Sitem Pendiidkan Nasional .

Ketika pertama kali diumumkan sebagai pandemic global pada Maret 2020. Oleh pemerintah pusat. Bersamaan dengan pengumuman tersebut sekolah-sekolah dilibur, untuk proses belajar mengajar antara guru dengan siswa mengunakan sistem jarak jauh (online). Dengan mempergunakan proses belajar mengajar jarak jauh akan membawa dampak pada guru dan juga siswa.

Dengan adanya pandemic covid 19 membawa dampak bagi pemenuhan hak atas pendidikan yang dimana proses belajar mengajar mengunakan sistem jarak jauh (online) Bagi masyarakat yang ekonomi diatas rata-rata tidak ada masalah, tetapi bagaimana dengan anakanak yang orang tua ekonomi lemah. Padahal Pendidikan adalah hak konstitusional, hak dasar yang dimiliki oleh setiap anak-anak usia sekolah, tanpa ada diskriminasi Apabila adanya diskriminasi dalam pemenuhan hak atas pendidikan, maka telah terjadi bentuk pelangaran oleh negara apakah berbentuk pembiaran (omnission) atau dalam bentuk tindakan (commission), Dan ini merupakan pelanggaran Hak Asasi Manusia.

Menurut Prinsip-prinsip Maastricht (Maastricht Principles) yang dirumuskan oleh ahliahli hukum internasional tentang tangung jawab negara berdasarkan Konvenan Economic, Social Cultural (CESCR) yang Indonesia sudah ratifikasi menjadi UU NO 11 tahun 2005 tentang hak-hak ekonomi ,sosial dan budaya.maka ada 3 tangung jawab pemerintah untuk menghormati, melindungi, dan memenuhi.Masing-masing mengandung unsur kewajiban mengenai tindakan (obligation conduct) dan kewajiban mengenai hasil (obligation result). Kewajiban mengenai tindakan membutuhkan langkah yang diperhitungkan dengan cermat untuk melaksanakan dipenuhinya hak atas pendidikan dasar.

Kesetaraan akses Internet pada fasilitas pendidikan terkait paling utama dengan prinsip non-diskriminasi. Setiap orang dengan latar belakang apapun harus memiliki akses yang sama terhadap fasilitas pendidikan yang disediakan oleh negara.Terkhusus pemerintah daerah harus memastikan bahwa kelompok-kelompok marginal juga harus mendapatkan akses internet atas fasilitas pendidikan yang memadai.

Berlakunya masa pandemic Covid -19 mengubah secara paksa pendidikan formal secara tatap muka menjadi pendidikan formal dengan bentuk pembelajaran daring. Berbagai tantangan atas kebutuhan pendidikan bergeser dari kebutuhan transportasi, ekonomi dan pembiayaan penunjang penyelengaraan pendidikan menjadi kebutuhan akan perangkat elektronik yang dapat terkoneksi melalui internet serta konektivitas internent tersendiri. Kondisi tersebut bukan hal yang mudah baik bagi penyelenagara pendidikan, pendidik maupun peserta didik

Hak atas pendidikan merupakan hak yang timbul dari kaedah hukum perjanjian internasional. Kaedah ini secara hukum mengikat negara yang telah meratifikasinya dan pada gilirannya melaahirkan tangungjawab bagi negara yang bersangkutan untuk memenuhinya. Sifat dan bentuk dan luas lingkup tangung jawab negara untuk memenuhi hak atas pendidikan 
ditentukan oleh disposisi perjanjian internasional, dalam hal ini adalah International convenan economic, social , cultural rights ${ }^{3}$

Penyebaran virus Corona di Ambon sangat berdampak terhadap pemenuhan pendidikan dasar bagi murid-murid Sekolah Dasar (SD) dan Sekolah menengah Pertama (SMP), khusus sekolah -sekolah negeri Hative Besar dan Desa Hunut, murid-murid ini harus mengikuti proses belajar mengajar secara Daring . Maka sangat dibutuhkan pemenuhan hak atas pendidikan dalam masa pandemic-19 yang menjadi tangung jawab pemerintah dan peran orang tua dalam menfasilitasi sarana dan prasarana yang dapat diakses dan terjangkau, sehingga proses belajar Daring dapat berhasil.

\section{B. METODE PENELITIAN}

Penelitian ini dilakukan dengan menggunakan pendekatan yuridis empiris yang bersifat kajian deskriptif analisis kualitatif. Penelitian berusaha menggambarkan bagaimana Pemenuhan Hak atas pendidikan dasar di Kota Ambon Selama Masa pndemic Covid-19. Cara kerja dari metode yuridis empiris atau yuridis sosiologis dalam usulan penelitian ini yaitu dari hasil pengumpulan dan penemuan data serta informasi melalui studi kepustakaan terhadap asumsi atau anggapan dasar yang dipergunakan dalam menjawab permasalahan pada penelitian ini, kemudian dilakukan pengujian secara induktif-verifikatif pada fakta mutakhir yang terdapat di dalam masyarakat. Dengan demikian kebenaran dalam suatu penelitian telah dinyatakan reliable tanpa harus melalui proses rasionalisasi. Lokasi dari penelitian ini berpusat pada wilayah Kota Ambon. Dari Kota Ambon kemudian diambil beberapa responden dari berbagai unsur yaitu: 1) Dinas Pendidikan dan Kebudayaan Kota Ambon, 2) Gugus Tugas Covid-19 Kota Ambon, 3) Kepala sekolah SD Negeri Hative Besar dan SD Kristen Hunut, 4) Kepala sekolah SMP Negeri 12 dan SMP Negeri 13 Negeri lama, 5) Orang tua dan siswa, SD, berjumlah 10 siswa dan SMP berjumlah 10 siswa.

\section{PEMBAHASAN}

\section{Kronologis Lokasi Penelitian}

Pandemic Covid-19 yang melanda kota Ambon, ini berdampak terhadap perubahan aktifitas belajar-mengajar. Sejak bulan maret akitvitas pembelajran daring menjadi sebuah pilihan Kementerian Pendidikan dan Kebudayaan untuk mecegah penyebaran virus pandemic covid-19 semakin meluas. Perubahan sangat cepat ini tanpa diiringi persiapan yang memadai sebelumnya, akibatnya banyak kendala yang dihadapi baik oleh guru maupun oleh siswa-siswa. Akibatnya banyak tenaga pendidik gagap menghadapi perubahan dratis ini. Sementara itu praktis tidak ada cara lain untuk meminimalisir penyebaran Covid -19 selain dengan membatasi perjumpaan manusia dalam jumlah yang banyak.

Pelaksanaan sistem pembelajaran dengan model daring selama masa pandemic belum berjalan secara optimal. Ada beberapa hal yang merusak kenyaman, terutama mengenai akses internet. Kemudian juga masalah orang tua dalam mendampingi anak-anak dirumah juga masih kurang karena banyak orang tua yang belum mengerti tentang sistem pendidikan. Dari hasil wawancara dengan ibu kepala sekolah SMP negeri 12 Ambon dan Ibu wakil kepala sekolah bagian Kurikulum SMP negeri 13 Negeri lama, dalam proses belajar mengajar digunakan 2 model secara daring dan secara luring. Dari 2 model pembelajaran ini juga guru menghadapi masalah.

Proses belajar mengajar secara luring (berkunjung kerumah siswa), pada setiap hari senin orangtua datang ke sekolah untuk mengambil modul dan buku paket untuk siswa belajar

\footnotetext{
3 Ashri, M. (2012). Hukum Perjanjian Internasional, Dari Pembentukan Hingga Akhir Berlakunya. Makassar: Arus Timur. h. 30$$
\text { 199|SASI Vo1. } 27 \text { No.2, April - Juni } 2021
$$ 
dirumah, nantinya dihari selasa dan hari kamis guru kerumah siswa untuk menerangkan apabila tugas yang diberikan lewat modul dan buku paket siswa tidak mengerti, nantinya dihari sabtu orang tua membawa tugas yang diberikan oleh guru kepada siswa.

Ada siswa-siswa yang menunggu guru datang untuk memberikan pelajaran tetapi ada juga yang siswa yang acuh terhadap kehadiran guru, apalagi tidak didukung oleh orang tua, dalam memberikan pelajaran secara luring. Sedangkan dalam proses belajar mengajar secara daring ada juga masalah karena dari siswa karena dirumah tidak ada jaringan internet, bantuan pulsa dari sekolah juga belum diterima oleh siswa-siswa.Dari hasil wawancara dengan siswa SMP negeri 12 yang bernama Natalia Mailuhu bahwa saya belajar secara daring membuat saya jenuh, kadang-kadang juga ganguan sinyal.

Dari hasil wawancara dengan kepala sekolah SD Kristen Hunut, Bapak J. Selanno, SPd dan Ibu Kepala Sekolah SD Negeri 2 Hative Besar, Ibu T. Patiasina.,Spd bahwa dalam proses belajar mengajar yang digunakan adalah model pembelajaran secara Luring, tetapi setiap hari senin ,orang tua datang kesekolah untuk mengambil buku paket dan modul,setiap hari guru berkunjung kerumah-rumah siswa untuk meerangkan, terkadang ketika guru berkunjung kerumah siswa , mereka tidak ada dirumah sementara membantu orang tua kehut.. siswa-siswa SD merasa dalam proses belajar mengajar mereka mengangap sebagai beban.

Pembelajaran jarak jauh (daring) yang dilaksanakan pada maret 2020. Mengacu pada surat edaran Kemendikbud No 40 tahun 2020, tentang pelaksanaan kebijakan pendidikan dalam masa darurat penyebaran corona virus disease, dampak virus 19, proses pembelajaran dilakukan dari rumah secara daring pada satuan pendidikan dengan mengunakan berbagai sumber belaajr melalui teknologi komunikasi, informasi, dan media yang mendukung secara konsepsi memiliki memiliki tujuan yang baik,

Pembelajaran jarak jauh yang dilakukan guru lewat media online seperti whatsapp, google meet, google form dan jenis lainnya. Namun demikian sistem ini perlu desain dan teknik pembelajaran yang khusus agar dapat diterapkan . Evaluasi kebijakan perlu dilakukan untuk mengevaluasi sistem pembelajaran jarak jauh yang selama ini dilaksanakan disekolah pada semua jenjang pendidikan.

Berdasarkan hasil pengamatan yang dilakukan penulis, diperoleh gambaran bahwa pembelajaran jarak jauh dinilai belum efektif dan maksimal apabila diterapkan pada sekolah yang infrastukturnya belum memadai. Hal ini dikarenakan pembelajaran jarak jauh berbasis teknologi memerlukan pendekatan yang berbeda dalam hal perencanaan,pelaksanaan dan evaluasinya. Pelaksanaan pembelajaran jarak jauh, peserta didik membutuhkan perhatian khusus, terutama saran prasarana yang digunakan, jaringan internet yang memadai dan motivasi diri agar dapat mengikuti proses belajar yang bersifat mandiri.

Permasalahan pembelajaran jarak jauh diantaranya adalah belum meratanya akses jaringan internet yang belum memadai, mahalnya biaya kuota, belum meratanya penguasaan iptek dikalangan pendidik atau guru, belum siapnya pelaksanaan proses belaajr mengajar jarak jauh, dan kesulitan orang tua dalam mendampingi anak-anaknya melakukan kegiatan belajar mengajar menjadi kendala yang ditemui selama proses pembelajaran jarak jauh ${ }^{4}$. Pemenuhan hak atas pendidikan ini merupakan tanggung jawab yang harus merupakan tanggungjawab Pemerintah berdasarkan Pasal 8 UU No 39 Tahun 1999 tentang Hak Asasi Manusia. Pemenuhan atas pendidikan dapat berhasil ketika menekankan perlindungan, pemajuan dan pemenuhan hak atas pendidikan itu sendiri ${ }^{5}$

\footnotetext{
4 Ruslan, M. (2008). Perlindungan Hukum Terhadap Anak. Jurnal Bilancia, 2(1), h.12

5 Affandi, H. (2017). Tanggungjawab Negara dalam Pemenuhan Hak Atas Pendidikan Menurut UndangUndang Dasar Tahun 1945. Jurnal Hukum: Positum, 1(2), 218-243. DOI: https://doi.org/10.35706/positum.v1i2.848, h. 218

$$
\text { 200|S ASI Vol. } 27 \text { No.2, April - Juni } 2021
$$
}


Beberapa solusi yang telah diberikan pemerintah adalah terdapat beberapa peraturan yang telah dengan jelas mengatur dan memberikan gambaran tentang bagaimana prsos pembejaran jarak jauh dilaksanakan seperti Surat Edaran No 15 Tahun 2020 tentang Pedoman Penyelengaraan Belajar Dari Rumah Masa Darurat penyerbaran Covid-19. Fleksibilitas pengunaan dana BOS untuk mensubsidi kuota guru dan siswa merupakan salah satu kebijakan yang dikeluarkan pemerintah dalam mengatasi mahalnya biaya kuota dalam rangka pelaksanan pembelajaran jarak jauh.Hal ini begutu pneting mengingat pemenuhan hak atas pendidikan tidak hanya tergantung pada pengaturan hukum tetapi komitmen pendaaan pendidikan oleh pemeerintah. ${ }^{6}$

Pendidikan di masa Pandemi Covid 19 tentu memberikan tantangan pada rancangan pembelajaran, proses pembelajran namun tidak pada tujuan pembelajaran. Sebagaimana ditegaskan dalam kebijakan PSBB yang menekankan pembatasan sosial, termasuk pelaksanaan pendidikan dirumah.

\section{Hak atas Pendidikan sebagai Bagian dari Hak Asasi Manusia (HAM)}

Deklarasi universal human rights (DUHAM) menekankan hak atas pendidikan lebih pada hal-hal penting yang harus ada untuk menjamin pemenuhannya. Pasal 26 ayat (1) DUHAM hak memperoleh pendidikan ini didasarkan pada 4 prinsip utama, pertama perinsip persamaan kesempatan,,kedua, prinsip penghargaan HAM,ketiga prinsip tolerasi demi perdamaian, keempat prinsip hak utama orang tua atas pemilihan pendidikan anak. ${ }^{7}$

HAM dimaksudkan sebagai hak yang dimiliki manusia berdasarkan martabatnya sebagai manusia. Manusia memilikinya karena ia adalah manusia ${ }^{8}$. Aswanto berpendapat bahwa: "Hak asasi manusia lahir bersamaan dengan kelahirannya yang memiliki harkat dan martabat sebagai manusia kodrat dan alami. Manusia dibedakan dengan makhluk biologis lainnya (tumbuhan dan hewan) karena harkat dan martabat yang dimiliki", maka HAM sesungguhnya bersifat kodrati dan karena itu pula, hak ini mendapat pengakuan negara tidak berwenang mencabut hak ini melainkan sebaliknya negara memiliki kewajiban untuk mengawal implementasi HAM setiap warga di wilayahnya.

Konsep HAM mencakup tiga elemen utama bagi eksistensi manusia sebagai makhluk individu maupun makhluk sosial, yaitu integritas manusia (human integrity), kebebasan (freedom) dan kesamaan (qeuality). ${ }^{10}$ Pemahaman atas pengertian ini menjadi jelas ketika pengakuan atas hak tersebut diberikan dan dipandang sebagai proses humanisasi manusia oleh pihak lain dalam konteks vertikal (individu dengan negara) dan horisontal (antar individu) baik secara de facto maupun de jure.

HAM adalah hak-hak yang diakui secara universal sebagai hak-hak melekat pada manusia karena hakikat dan kodarat kelahirannya sebagai manusia. Dinyatakan "universal" karena hak-hak ini merupakan bagian dari eksistensi kemanusiaan setiao orang, tanpa

\footnotetext{
${ }^{6}$ Sujatmoko, E. (2016). Hak warga negara dalam memperoleh pendidikan. Jurnal Konstitusi, 7(1), 181212. DOI: https://doi.org/10.31078/jk\%25x, h. 181

7 Ali, S. K. (2013). Cultural and Educational Rights of Minorities: A Human Right and Constitutional Law Perspective. Indian Journal for Social Studies and Humanities, 1(2). h. 114

8 Suseno, F. M. (2001). Etika Politik (Prinsip-Prinsip Moral DasarKenegaraan Modern). Jakarta: Gramedia, h. 121

9 Aswanto, Filosofi Hak Asasi Manusia Serta Penegakannya Dalam Perspektif Negara Hukum (Makalah disampaikan pada seminar/sosialisasi kemampuan Bidang hukum kepada seluruh perwira Hukum Polda Sulsel dan jajaranya), h. 3-4

10 Triyana, H. J. (2005). "Komentar Hukum atas putusan Mahkamah Konstitusi Perkara No. 012/PUU/III/2005 mengenai Pengujian Undang-Undang No 36 Tahun 2004 tentang Anggaran Pendapatan dan Belanja Negara". Jurnal Hukum dan HAM Bidang Pendidikan (Biru Hukum dan Organisasi Depdiknas Jakarta), 3 (2). h. 235. Mengutip Manfred Nomak, The Right to Education dalam Asbjorn Eide (ed. All), Economic, Sosial and Cutural Right: A Textboook (1995), h. 196
}

$$
\text { 201|S A S Vol. } 27 \text { No.2, April - Juni } 2021
$$


membedakan warna kulit, jenis kelamin, usia, etnis dan budaya, agama atau keyakinan spiritualitasnya. Hak tersebut melekat pada kodrat kelahirannya sebagai manusia dan bukan berasal dari pemberian suattu organisasi kekuasaan manapun. ${ }^{11}$

Selain untuk "universal" dan "melekat" pada manusia, dalam istilah hak asasi manusia, terkandung pula lima prinsip dasar yang menjadi acuan dalam menegakkan nilai-nilai hak asasi manusia, yaitu :

a) Equality (Kesetaraan), adalah ekspresi dari konsep untuk menghormati manusia sebagai umat yang merdeka dan sederajat dalam harkat dan martabatnya

b) Non-discrimination (non diskriminasi) menunjukkan bahwa tidak seorangpun dapat ditiadakan eksistensinya karena latar belakang ras, warna kulit, jenis kelamin, bahasa agama, keyakinan politik atau ideologi, dan kebangsaan atau kewarganegaraan

c) Indivisibility (tak terbagi), hak asasi manusia adalah menyatu, tidak dapat dipisahkan-pisahkan termasuk di dalamnya adalah hak sipil-politik, hak ekonomi, sosial budaya dan hak-hak kolektif

d) Interdependence (saling bergantunga), menunjukkan bahwa pemenuhan suatu hak asasi manusia bergantung pada pemenuhan hak lainnya, baik sebagaian maupun seluruhnya

e) Responsibility (tanggung jawab), menegaskan setiap negara, individu, dan entitas lain (korporasi, organisasi-organisasi non pemerintah dan lainnya) wajib bertanggung jawab dalam perlindungan dan pemenuhan $\mathrm{HAM}^{12}$

Jean JacQues Rousseau menguangkapkan dalam karyanya Du Contract social manusia itu lahir bebas dan sejerajat dalam hak-haknya, sedangakan hukum merupakan ekspresi dan kehendak umum (rakyat) ${ }^{13}$, berdasarkan pada pandangan ini tidak boleh terjadi perlakuan diskriminasi, misalnya perlakuan yang tidak membedakan suku, agama,ras,golongan, jenis kelamin, budaya, bahasa serta kondisi fisik anak.

\section{Tanggungjawab Pemerintah Daerah dalam Pemenuhan Pendidikan Dasar}

Tanggungjawab Pemerintah Daerah Kabupaten/Kota dalam mengelola urusan pendidikan dasar merupakan konsekuensi dari penerapan desentralisasi atau penyerahan urusan pendidikan dasar kepada daerah Kabupaten/Kota. Hal ini sebagai upaya untuk meningkatkan pelayanan pemerintahan dibidang pendidikan dasar kepada masyarakat ${ }^{14}$

Good governance hanya bisa dicapai apabila pemerintah dalam melaksanakan tugasnya berpedoman pada konsep rule of law yang mempunyai empat karakteristik, 1)pemerintah melaksanakan kewenangan berdasarkan supremasi hukum,2) pemerintah menjamin kepastian hukum,3) peemrintah harus mampu menciptakan hukum yang responsif yang mampu menterap aspirasi masyarakat, 4) pemerintah harus melaksanakan hukukm secara konsisten dan non diskriminatif. ${ }^{15}$

Penyerahan urusan pendidikan dasar kepada daerah merupakan salah satu model pengelolaan pendidikan yang menjadikan pemerintah daerah sebagai aktor utama dalam

\footnotetext{
${ }^{11}$ Ashri, M. (2018). Hak Asasi Manusia: Filosofi, Teori \& Instrumen Dasar. Makassar: Social Politic Genius (SIGn), h. 2-3

12 Flowers, N. (2000). The Human Rights Education Handbook: Effective Practices for Learning, Action, and Change. Human Rights Education Series, Topic Book. Human Rights Resource Center, University of Minnesota, 229 19th Avenue South, Room 439, Minneapolis, MN 55455. p. 7

13 Wiratraman, R.H.P. (2005). Konstitusionalisme \& Hak-Hak Asasi Manusia: Konsepsi Tanggung Jawab Negara dalam Sistem Ketatanegaraan Indonesia. Jurnal Ilmu Hukum Yuridika, 20(1), 1-17.

14 Wiratraman, R.H.P. (2005). Konstitusi \& Hak-Hak Asasi Manusia Konsepsi Tangugnjwab Negara Dalam Sistem Ketatanegaraan Indonesia. Jurnal Pusat Kajian Kinerja Otonomi Daerah, 10(5). h. 24

15 Fahmi, S. (2011). Asas Tanggung Jawab Negara Sebagai Dasar Pelaksanaan Perlindungan dan Pengelolaan Lingkungan Hidup. Jurnal Hukum Ius Quia Iustum, 18(2), 212-228. h. 212
} 
mengambil keputusan serta melaksanakan tindakan pemerintahan di bidang pendidikan yang disesuaikan dengan kondisi daerah. Pemerintah daerah kabupaten atau kota merupakan struktur pemerintah negara yang lebih dekat dengan masyarakat dan lebih memahami kebutuhan pelayanan pendidikan dasar di masing-masing daerah.

Menurut Didin Nurdin bahwa dengan diberikan wewenang mengelolah urusan pendidikan dasar melahirkan tanggungjawab penuh dari pemerintah daerah Kabupaten/Kota untuk membangun pendidikan dasar yang lebih berkualitas dengan memperbaiki kelemahankelemahan persoalan pendidikan. Dengan demikian desentralisasi pendidikan membuka peluang untuk memperbaiki dan meningkatkan kualitas pendidikan di daerah. ${ }^{16}$

Urusan pendidikan merupakan salah satu dari bagian urusan wajib yang berkaitan dengan pelayanan dasar. Urusan pemerintahan wajib yang berkaitan dengan pelayanan dasar adalah urusan pemerintahan wajib yang sebagian substansinya merupakan pelayanan dasar. Pelayanan dasar merupakan pelayanan publik untuk memenuhi kebutuhan dasar warga negara.

Pada prinsipnya dalam suatu negara hukum termasuk Indonesia, hukum menjadi dasar mengatur serta menguji segala tindakan atau perbuatan serta melindungi seluruh hak atau kepentingan seluruh subjek hukum kehidupan bermasyarakat, berbangsa dan bernegara. Dengan demikian penyerahan urusan pendidikan dasar dari pemerintah pusat kepada daerah atau kabupaten atau kota serta pengelolaan pendidikan dasar oleh pemerintah daerah kabupaten atau kota harus berdasarkan pada aturan hukum yang berlaku.

Penyerahan urusan pendidikan dasar kepada daerah Kabupaten/Kota ditetapkan dalam pasal 50 ayat 5 UU Nomor 20 Tahun 2003 yang mengatur bahwa Pemerintah Daerah Kabupaten/Kota mengelolah Pendidikan Dasar serta satuan Pendidikan yang berbasisi keunggulan lokal. Selain itu juga ditetapkan dalam pasal 12 ayat 1 huruf a UU Nomor 23 Tahun 2014 yang mengatur bahwa Urusan Pemerintahan wajib yang berkaitan dengan pelayanan dasar sebagaimana dimaksud dalam pasal 11 ayat 2 meliputi : a. Pendidikan, b. Kesehatan, c. Pekerjaan Umum dan Penataan Ruang, d. Perumahan rakyat dan kawasan pemukiman, e. Ketentraman, ketertiban umum dan Perlindungan masyarakat, f. Sosial.

Dalam konteks Internasional Convenan Economic Social, Cultural Right (ICESCR), tanggungjawab yang melahirkan kewajiban negara untuk memenuhi hak atas pendidikan adalah kewajiban untuk menghormati (to respect), melindungi (to protect), dan memenuhi (to fulfil) $)^{17}$ dalam taran kewajiban atas hasil (obligation to result) dan bukan merupakan kewajiban bertindak (obligation to cunduct), sebagaimana pada hak-hak sipil dan politik. Kewajiban negara menjadi terpenuhi apabila negara dengan itikad baik telah memanfaatkan sumber daya maksimal yang tersedia (maximum available resources) dan telah melakukan realisasi secara progresif (porgressive realization) ${ }^{18}$. Dalam konteks inilah maka konferensi Dunia tentang HAM di wina, 25 Juni 1993 mendeklarasikan perlunya keharusan adanya usaha yang terencana untuk menjamin pengakuan atas hak ekonomi, sosial dan budaya pada tingkat nasional, regional dan internasional. Pengaturan konvenan Hak Ekosob lebih luas tidak hanya berfokus pada hak untuk memperoleh pendidikan sebagai kunci dari pemenuhan hak ekonomi sosial dan budaya seseorang di masyarakat. ${ }^{19}$

${ }^{16}$ Nurdin, D., \& Sibaweh, I. (2015). Pengelolaan Pendidikan Dari Teori Menuju Implementasi. Jakarta: Raja Grafindo Persada, h. 41

17 UIN, T. I. (2003). Demokrasi, Hak Asasi Manusia \& Masyarakat Madani. Jakarta: Kencana, h. 231

18 Nowak, M. (2003). Introduction to the international human rights regime. Brill Nijhoff Publishers. Raoul Wallenberg Institute, h. 87

19 Viviansari, D. B., Prameswari, Z. W. A. W. (2019). Tanggung Jawab Negara terhadap Pemenuhan Hak atas Pendidikan Anak Buruh Migran Indonesia di Malaysia. Jurnal HAM, 10 (2). DOI: http://dx.doi.org/10.30641/ham.2019.10.179-194 h. 179

$$
203 \text { |S A S I Vol. } 27 \text { No.2, April - Juni } 2021
$$




\section{Peran Orang Tua dalam Pemenuhaan Hak atas Pendidikan.}

Orang tua dalam kaitan dengan pendidikan anak adalah sebagai pendidik utama, maka dari itu tangung jawab orang tua terhadap pendidikana diantaranya memberikan dorongan atau motivasi, baik kasih sayang, tangung jaawab moral,tangung jawab sosial dan tangung jawab atas kesejahteraan anak baik lahir maupun batin. Orang tua adalah pendidik utama dan alami, karena ketika anak bertumbuh dan berkembang orang tuanyalah yang berperan aktif dalam memelihara, memberi asupan dan pendidikan keluarga. Oleh karena itu anak-anak didik tentunya dengan berbagai autran yang harus dijalankan oleh anak. Orang tua secara langsung akan memberikan didikan kepada anak, baik berkaitan dengan pendidikana formal ,maupun pendidikan agama.

Peran orang tua dalam pendampingan belajar anak, dapat dijelaskan bahwa sebagian besar peran itu dijalankan oleh Ibu ,sesuai dengan kontruksi gender patriarhie, ayah berperan mencari nafkah, sehingga kegiatan pendampingan anak tanpa disadari ditelah disepakati dikerjakan oleh ibu, ${ }^{20}$ sebagai orang tua tentunya akan bertangung jawab untuk mempersiapkan anak-anaknya menjadi manusia berguna. Dimasa pandemic ini, orang tua harus menjadi pendamping setia saat anak-anak belajar dengan mempergunakan sistem jarak jauh mengerjakan tugas yang diberikan gurunya, orang tua harus mendampinginya.

Dimasa pandemic ini orang tua juga bertindak sebagai guru pertama. Oleh karena itu, selain tugas rutin mendampingi anak-anak belajar dirumah, orang tua mau tidak mau, suka tidak suka, harus belajar dan beradaptasi dengan pola pembelajaran yang sedang diterapkan pemerintah, yakni pembelajaran jarak jauh (Daring). Tentunya orang tua harus belajar dan tidak gagap teknologi (gaptek).

\section{PE N T U P}

Pemenuhan hak atas pendidikan merupakan bagian dari HAM, dalam proses pembelajaran mengunakan 2 model, yakni model Daring dan model Luring. Pemenuhan hak atas pendidikan tidak hanya terbaats pada pelaksanaan pendidikan akan tetapi keterlibatan semua pihak untuk saling memenuhi hak atas pendidikan dasar. Maka diperlukan tangungjawab pemerintah kota dan peran orang tua dalam pendampingan bagi anak dalam proses belajar mengajar. Masa pandemi Covid-19 memberikan tantangan baru bagi pemerintah, pendidik, peserta didik dan institusi penyelengara pendidikan pada tataran praktis untuk mengembangkan metode pembelajaran yang inovativ dengan mengunakan keungulan teknologi informasi.. Kemampuan penguasan teknologi informasi (digital literacy) perlu ditingkatkan melalui pelatihan pembelajaran daring baik kepada tenaga pendidik, peserta didik, maupun orang tua.

\section{DAFTAR PUSTAKA}

\section{Jurnal}

[1] Affandi, H. (2017). Tanggungjawab Negara dalam Pemenuhan Hak Atas Pendidikan Menurut Undang-Undang Dasar Tahun 1945. Jurnal Hukum: Positum, 1(2), 218-243. DOI: https://doi.org/10.35706/positum.v1i2.848.

[2] Ali, S. K. (2013). Cultural and Educational Rights of Minorities: A Human Right and Constitutional Law Perspective. Indian Journal for Social Studies and Humanities, 1(2).

[3] Fahmi, S. (2011). Asas Tanggung Jawab Negara Sebagai Dasar Pelaksanaan Perlindungan dan Pengelolaan Lingkungan Hidup. Jurnal Hukum Ius Quia Iustum, 18(2), 212-228.

[4] Ruslan, M. (2008). Perlindungan Hukum Terhadap Anak. Jurnal Bilancia, 2(1).

[5] Sujatmoko, E. (2016). Hak warga negara dalam memperoleh pendidikan. Jurnal

20 Sabiq, A. F. (2020). Persepsi Orang Tua Siswa tentang Kegiatan Belajar di Rumah sebagai Dampak Penyebaran Covid 19. Civic-Culture: Jurnal Ilmu Pendidikan PKn dan Sosial Budaya, 4(1 Extra), 1-7, h. 7 
Konstitusi, 7(1), 181-212. DOI: https://doi.org/10.31078/jk\%25x.

[6] Sabiq, A. F. (2020). Persepsi Orang Tua Siswa tentang Kegiatan Belajar di Rumah sebagai Dampak Penyebaran Covid 19. Civic-Culture: Jurnal Ilmu Pendidikan PKn dan Sosial Budaya, 4(1 Extra), 1-7.

[7] Triwahyuningsih, S. (2018). Perlindungan Dan Penegakan Hak Asasi Manusia (Ham) Di Indonesia. Legal Standing: Jurnal Ilmu Hukum, 2(2), 113-121. DOI:http://dx.doi.org/10.24269/1s.v2i2.1242. 10.24853/baskara.2.2.83-92.

[8] Triyana, H. J. (2005). Komentar Hukum atas putusan Mahkamah Konstitusi Perkara No. 012/PUU/III/2005 mengenai Pengujian Undang-Undang No 36 Tahun 2004 tentang Anggaran Pendapatan dan Belanja Negara. Jurnal Hukum dan HAM Bidang Pendidikan, $3(2)$.

[9] Viviansari, D. B., Prameswari, Z. W. A. W. (2019). Tanggung Jawab Negara terhadap Pemenuhan Hak atas Pendidikan Anak Buruh Migran Indonesia di Malaysia. Jurnal HAM, 10 (2). DOI: http://dx.doi.org/10.30641/ham.2019.10.179-194.

[10] Wiratraman, R.H.P. (2005). Konstitusionalisme \& Hak-Hak Asasi Manusia: Konsepsi Tanggung Jawab Negara dalam Sistem Ketatanegaraan Indonesia. Jurnal Ilmu Hukum Yuridika, 20(1), 1-17.

[11] Wiratraman, R.H.P. (2005). Konstitusi \& Hak-Hak Asasi Manusia Konsepsi Tangugnjwab Negara Dalam Sistem Ketatanegaraan Indonesia. Jurnal Pusat Kajian Kinerja Otonomi Daerah, 10(5).

\section{Buku}

[12] Ashri, M. (2012). Hukum Perjanjian Internasional, Dari Pembentukan Hingga Akhir Berlakunya. Makassar: Arus Timur.

[13]Ashri, M. (2018). Hak Asasi Manusia: Filosofi, Teori \& Instrumen Dasar. Makassar: Social Politic Genius (SIGn).

[14]Flowers, N. (2000). The Human Rights Education Handbook: Effective Practices for Learning, Action, and Change. Human Rights Education Series, Topic Book. Human Rights Resource Center, University of Minnesota, 229 19th Avenue South, Room 439, Minneapolis, MN 55455.

[15] Nowak, M. (2003). Introduction to the international human rights regime. Brill Nijhoff Publishers. Raoul Wallenberg Institute.

[16]Nurdin, D., \& Sibaweh, I. (2015). Pengelolaan Pendidikan Dari Teori Menuju Implementasi. Jakarta: Raja Grafindo Persada.

[17] Suseno, F. M. (2001). Etika Politik (Prinsip-Prinsip Moral DasarKenegaraan Modern). Jakarta: Gramedia.

[18]UIN, T. I. (2003). Demokrasi, Hak Asasi Manusia \& Masyarakat Madani. Jakarta: Kencana.

\section{Online/World Wide Web dan Lain-Lain}

[19]Aswanto, Filosofi Hak Asasi Manusia Serta Penegakannya Dalam Perspektif Negara Hukum (Makalah disampaikan pada seminar/sosialisasi kemampuan Bidang hukum kepada seluruh perwira Hukum Polda Sulsel dan jajaranya).

[20]Education is both a human in itself and an indispensable means other human rights. As an empowerment rights, education is the primary vehicle by which economically and socially marginalized adults and children can lift themselves out of poverty and obtain the means to participate fully in their communities " Lihat General comenment nomor 13: The right to education (art 13). 